| Research Article / Araştırma Makalesi |

\title{
The Relationship between Organisational Support and Teacher Leadership Perceptions of High School Teachers
}

\section{Liselerde Görev Yapan Öğretmenlerinin Örgütsel Destek ile Öğretmen Liderliği Algıları Arasındaki iliş̧ki}

\section{Emine Dağlı ${ }^{1}$, Fatma Kalkan ${ }^{2}$}

\author{
Keywords \\ 1. Organisational \\ support \\ 2. Teacher leadership \\ 3. High schools
}

\section{Anahtar Kelimeler \\ 1. Örgütsel destek \\ 2. Öğretmen liderliği \\ 3. Lise}

Received/Başvuru Tarihi 13.01.2021

Accepted / Kabul Tarihi 29.10.2021

\section{Abstract}

Purpose: The main purpose of this study is to determine the relationship between organisational support and teacher leadership perceptions of high school teachers.

Design/Methodology/Approach: The population of this study, which was designed in the relational screening model, consists of teachers working in state high schools in the central districts of Hatay in the 2018-2019 academic year. 298 teachers were selected through the random selection method. The research data collected by the "Perceived Organisational Support Scale" and "Teacher Leadership Scale" were analysed via arithmetic means frequency values, percentage, standard deviation, Kruskal Wallis test, Mann Whitney U test, Pearson product of moments, and simple linear regression analysis.

Findings: According to the results, it was determined that teachers' perceptions of organisational support and teacher leadership are high. Teachers' perceptions of the teacher leadership's dimension of collaboration with colleagues differ significantly according to seniority and educational status variables. It has been observed that teachers working in schools accepting students without examination have a higher perception of organisational support than teachers working in schools that accept students with aptitude tests. There is a moderately positive significant relationship between teachers' perceptions of organisational support and teacher leadership. The study determined that organisational support is a significant predictor of the sub-dimensions of teacher leadership, institutional development, professional development, and collaboration with colleagues.

Highlights: Teachers who accept students without an exam have a higher perception of organisational support than teachers who accept students with aptitude tests. This shows that the school type is an important variable. In this direction, qualitative studies can be conducted to gain in-depth information on why the perception of organisational support differs according to school types. Considering that organisational support is a predictor of teacher leadership, it can be stated that there is a need for studies to determine the factors affecting teachers' perceptions of organisational support.

Öz

Çalışmanın amacı: Bu araştırmanın temel amacı, liselerde görev yapan öğretmenlerin örgütsel destek ve öğretmen liderliği algıları arasındaki ilişkilerin tespit edilmesidir.

Materyal ve Yöntem: Ilişkisel tarama modelinde tasarlanmış olan bu araştırmanın evrenini 2018-2019 eğitim öğretim yılında Hatay ili merkez ilçelerinde bulunan resmi ortaöğretim okullarında görev yapan öğretmenler oluşturmaktadır. Seçkisiz örnekleme yöntemiyle 298 öğretmen katılımcı araştırma örneklemi için seçilmiştir. "Algılanan Örgütsel Destek Ölçeği” ve "Öğretmen Liderliği Ölçeği” ile toplanan araştırma verileri, aritmetik ortalama frekans değerleri, yüzde, standart sapma, Kruskal Wallis testi, Mann Whitney $U$ testi, Pearson momentler çarpımı ve basit doğrusal regresyon analizi ile analiz edilmiştir.

Bulgular: Sonuçlara göre, öğretmenlerin örgütsel destek ve öğretmen liderliği algılarının yüksek düzeyde olduğu tespit edilmiştir. Öğretmenlerin öğretmen liderliğinin meslektaş işbirliği boyutuna dair algıları, kıdem ve eğitim durumu değişkenine göre anlamlı düzeyde farklılaşmaktadır. Sınavsız öğrenci alan okullarda çalışan öğretmenlerin, yetenek sınavı ile öğrenci alan okullarda çalışan öğretmenlere göre daha yüksek örgütsel destek algısına sahip oldukları görülmüştür. Öğretmenlerin örgütsel destek ve öğretmen liderliği algıları arasında orta düzeyde, pozitif anlamlı bir ilişki vardır. Araştırmada, örgütsel desteğin öğretmen liderliğinin kurumsal gelişme, mesleki gelişme ve meslektaş işbirliği alt boyutlarının anlamlı bir yordayıcısı olduğu tespit edilmiştir.

Önemli Vurgular: Sınavsız öğrenci alan okullarda çalışan öğretmenlerin, yetenek sınavı ile öğrenci alan okullarda çalışan öğretmenlere göre daha yüksek örgütsel destek algısına sahip olmaları, okul türünün örgütsel destek algısı üzerinde önemli bir değişken olduğunu göstermektedir. Bu doğrultuda, okul türüne göre örgütsel destek algısının neden farklılık gösterdiği üzerine derinlemesine bilgi edinmek için nitel çalışmalar yapılabilir. Örgütsel desteğin, öğretmen liderliğinin bir yordayıcısı olduğu göz önünde bulundurulursa, öğretmenlerin örgütsel destek algılarını etkileyen faktörlerin belirlenmesine yönelik çalışmaların yapılmasına ihtiyaç olduğu ifade edilebilir.

${ }^{1}$ Corresponding Author, Hatay Mustafa Kemal University, Faculty of Education, Department of Primary Education, Hatay, TURKEY; eminedaglim@gmail.com, https://orcid.org/0000-0001-6518-0282

2 Şehit Öğretmen M. Ali Durak Ortaokulu, Ankara, TURKEY; https://orcid.org/0000-0002-2425-2224 


\section{INTRODUCTION}

Various theories and concepts are put forward to understand, explain, predict, and control the behaviour of employees in the organisational environment. Therefore, a theory that comes to the fore in the literature is social change. According to the social change theory, when employees feel supported by their organisations, they reflect these feelings as positive attitudes and behaviours towards their organisations (Uzun, 2018). In other words, the perception of organisational support is an element that shapes employees behaviours. Perceived organisational support is defined as employees' perceptions about how much importance is attached to their contributions to the organisation and how much attention is paid to their welfare (Eisenberger, Huntington, Hutchison, and Sowa 1986).

The fact that the employees in the organisation feel safe and know that the organisation is behind them is an indicator of perceived organisational support (Özdevecioğlu, 2003, p. 113). Perceived organisational support meets employees' socioemotional needs such as respect, attachment, and emotional support (Eisenberger \& Stinglhamber, 2011). Employees who feel cared for and valued in the organisation tend to develop an emotional commitment to the organisation (Tsui, Pearce, Porter, \& Tripoli, 1997). Rewarding the efforts of employees in the organisation to achieve a job, appreciating their contribution to the organisation, and paying attention to their well-being, etc., are all indicators of perceived organisational support (Eisenberger et al., 1986).

Organisational support has many positive effects on employees and the organisation. Employees who perceive organisational support have increased creativity, responsibility, job satisfaction, organisational commitment, organisational citizenship behaviours, and decreased feelings of stress, exhaustion, absenteeism, and quitting (Akın, 2008). As a result of the research, it has been revealed that organisational support increases employees' performance and organisational commitment (Bishop, 2000; Cropanzano, 1999; Erdoğan \& Ender, 2007; Meyer et al., 2002). Perceived organisational support is also related to employees' psychological well-being and positive attitudes towards their jobs (Eisenberger \& Stinglhamber, 2011; Rhoades \& Eisenberger, 2002). While perceived organisational support leads to organisational citizenship behaviours (Rhoades \& Eisenberger, 2002; Riggle, Edmondson, \& Hansen, 2009; Wayne, Shore, \& Liden, 1997), there are significant relationships between executive support and emotional attachment (Hutchinson, 1997). Rhoades and Eisenberger (2002) found that perceived organisational support increases the likelihood of employees doing their jobs with more enjoyment and being more positive. Hence, it has been determined that burnout, stress, headache, and anxiety are less common.

Organisational support effectively creates suitable conditions for employees to perform their duties and responsibilities in the best way. However, apart from other organisations, the effect of organisational support in educational institutions is not limited to this. When teachers feel supported, they contribute more towards achieving the school's goals and feel more secure and peaceful (Nayır, 2012). Perceived organisational support positively affects teachers' emotions towards teaching and can increase teachers' feelings of pride, pleasure, and hope (Argon \& Yilmaz, 2019). Literature studies show that organisational support is positively related to teachers' perceptions of organisational support, organisational trust (Eğriboyun, 2013; Uzun, 2018), organisational identification levels (Uzun, 2018), job performances, job satisfaction, and work engagement (Chinomona \& Sandada, 2014; Meriç, Çiftçi, \& Yurtal, 2019; Miao, 2011; Way, Sturman, \& Raab, 2010). Furthermore, it is negatively related to intentions to leave (Uzun, 2018) and organisational cynicism attitudes (Gökyer \& Türkoğlu, 2018). As a result of a meta-analysis conducted by Kasalak (2020), it was determined that teachers' perceptions of organisational support led to positive organisational outcomes such as organisational trust, organisational identification, organisational citizenship behaviours, work commitment, organisational commitment, and proactive work behaviour.

Unlike traditional school leadership and the limitations of official authority on leadership, the concept of "teacher leadership" (Kılıç ve Recepoğlu, 2013) has emerged to be an essential tool for school development. School management ensures the distribution of power and authority among teachers to develop teacher leadership (Muijs \& Harris, 2006). The essence of teacher leadership lies in transforming schools into learning organisations, supporting teachers to become more equipped in this process, and ensuring that schools have a more democratic climate (Beycioğlu \& Aslan, 2012).

Teacher leadership includes serving teachers individually as coaches or consultants, organising the curriculum, leading the department, developing programs or materials, coordinating professional development, supporting action research, managing the distribution of materials required for teaching, and participating in decision making (Harris \& Muijs, 2005). According to York-Barr and Duke (2004), teacher leadership is the process of influencing teachers' colleagues, principals, and other members of the school to improve their teaching and learning practices to increase student learning and success. Teacher leadership includes enhancing professional development and shared policies and decision-making processes. Teacher leadership aims to improve student learning and facilitate school change and development (Wenner \& Campbell, 2017). According to Can (2007), teacher leadership is the ability of teachers to support the development of their colleagues by influencing the formal processes of the classroom and school, being willing, and taking an active role in planned activities throughout the school. Teacher leadership is essential for school and student success. Studies in the literature show that teacher leadership is related to academic success (Eker, 2019; Sugg, 2013). Moreover, Teacher leadership also causes an increase in teachers' organisational citizenship behaviours (Uğurlu \& Yiğit, 2014), while decreasing their stress levels (Kılınç, Cemaloğlu, \& Savaş, 2015).

Developing teachers' qualifications and leadership skills for their students are very important in terms of school effectiveness (Koşar, Er, Kılınç, \& Koşar, 2017). It can be stated that with the development of teacher leadership, the success of schools and

| Kastamonu Education Journal, 2021, Vol. 29, No. 5 | 
students will increase (Beycioğlu \& Aslan, 2012). It is necessary to provide a collaborative working environment for all individuals to learn together and strengthen teachers' self-efficacy perceptions to increase the leadership behaviours of teachers in a school (Kurt, 2016). While the supportive behaviours of the principal strengthen teacher leadership (Eker, 2019; Savaş, 2016), the existence of a supportive school climate in the school and the cooperation of teachers with their colleagues will contribute to the increase of teacher leadership behaviours (Öztürk \& Şahin, 2017). According to Inanır (2020), teachers' integration with work will positively increase with a supportive school climate and teacher leadership.

Literature reviews provide limited information on the conditions necessary for teachers to exhibit leadership behaviours. Other organisational variables that are effective in teacher leadership should also be determined. Organisational support seems likely to be one of these variables because employees who perceive that they are valuable and important to the organisation will make more effort to achieve the organisation's goals or increase its efficiency (Büyükgöze \& Kavak, 2017). Organisational support can provide the organisational motivation that mobilises employees and directs their behaviour (Eisenberger et al. 1986). This organisational motivation can create the necessary environment for employees to reveal their potential leadership skills. When it comes to educational organisations, teachers motivated by the perception of organisational support are more likely to lead the process of planning and implementing instructional activities, actively managing the process, to collaborate and interact with colleagues in the teaching process. In other words, organisational support is crucial for teacher leadership. Nonetheless, no studies on the relationship between organisational support and teacher leadership in the literature were examined.

\section{Purpose of the Research}

The main purpose of this study is to examine the relationships between teachers' perceptions of organisational support and their perceptions of teacher leadership. In line with this purpose, the problem sentence of the research is "Is there a relationship between organisational support and teacher leadership according to the opinions of teachers working in high schools?" and the answers to the following questions were sought:

1. What are the perception levels of organisational support and teacher leadership of high school teachers?

2. Do high school teachers' perceptions of organisational support and teacher leadership differ according to gender, age, professional seniority, educational status, and high school type variables?

3. Is there a significant relationship between the perception levels of organisational support and teacher leadership of high school teachers?

4. Are organisational support perception levels of high school teachers a significant predictor of their teacher leadership perceptions?

\section{METHOD}

This research was designed through the relational survey model. The explanatory and predictive correlations revealed the teachers' perceptions of organisational support and leadership. The study's independent variable is based on perceived organisational support, while the dependent variable is on teacher leadership's sub-dimensions of institutional development, professional development, and collaboration with colleagues.

\section{Population and Sample}

The population consists of 1227 teachers working in 36 state high schools in the central districts of Hatay province in the 20192020 academic year. Using the sample calculation formula (Büyüköztürk, Çakmak, Akgün, Karadeniz, \& Demirel, 2010), it was calculated that 293 teachers from 36 public high schools should be included in the sample at a significance level of .05, and data was collected from 350 teachers from 15 public high schools. However, it was seen that the data collection tool of 52 participants was not suitable for analysis, and the data obtained from these tools were not included in the analysis. Therefore, the sample was formed through 298 randomly selected teachers from 15 schools. The demographic information of the participants is presented in Table 1 below. 
Table 1. Demographic information of the participants $(n=298)$

\begin{tabular}{|c|c|c|c|}
\hline & & $\mathbf{n}$ & $\%$ \\
\hline \multirow{3}{*}{ Gender } & Female & 121 & 40.6 \\
\hline & Male & 146 & 49.0 \\
\hline & Total & 267 & 89.6 \\
\hline \multirow{5}{*}{ Age } & $20-30$ years old & 23 & 7.7 \\
\hline & $31-40$ years old & 101 & 33.9 \\
\hline & $41-50$ years old & 114 & 38.3 \\
\hline & 51 years old and over & 52 & 17.4 \\
\hline & Total & 290 & 90.3 \\
\hline \multirow{4}{*}{ Professional Seniority } & $0-10$ years & 59 & 19.8 \\
\hline & $11-20$ years & 113 & 37.9 \\
\hline & $11-15$ years & 101 & 33.9 \\
\hline & Total & 273 & 91.6 \\
\hline \multirow{4}{*}{ Educational status } & Associate degree & 7 & 2.3 \\
\hline & Undergraduate & 219 & 73.5 \\
\hline & Graduate & 46 & 15.4 \\
\hline & Total & 272 & 91.3 \\
\hline \multirow{4}{*}{ High School Type } & High schools that accept students without an examination & 121 & 40.6 \\
\hline & High schools that accept students with an examination & 145 & 48.7 \\
\hline & High schools that accept students with a special talent examination & 32 & 10.7 \\
\hline & Total & 298 & 100 \\
\hline
\end{tabular}

\section{Data Collection Tools}

The data were collected by the "Perceived Organisational Support Scale", "Teacher Leadership Scale", and demographic information forms.

Perceived Organisational Support Scale (POSS): POSS developed by (Eisenberger et al. 1986) and adapted to Turkish by Akın (2008) was used to measure teachers' perceptions of organisational support. The original scale consists of 36 items. However, within the current study, a short form of the scale consisting 16 items based on one single dimension was used. The scale is 7point Likert type and has values in the range of "strongly disagree (1)" and "totally agree (7)". The internal consistency coefficient of the scale was found to be .94. Confirmatory Factor Analysis (CFA) was applied to test the scale's construct validity. The results of DFA; $\mathrm{X}^{2}=388.47, \mathrm{df}=104(\mathrm{p}=.00), \mathrm{X}^{2} / \mathrm{sd}=3.74, \mathrm{GFI}=.80, \mathrm{AGFI}=.74, \mathrm{RMSEA}=.086, \mathrm{NFI}=.95, \mathrm{SRMR}=.070, \mathrm{CFI}$ $=.96$ were determined to be within the acceptable value limits (Çokluk, Şekercioğlu, \& Büyüköztürk 2012; Meydan \& Şeşen, 2011; Schermelleh-Engel, Moosbrugger, \& Hans, 2003).

Teacher Leadership Scale (TLS): TLS developed by Beycioğlu and Aslan (2010) was used in the study to measure teachers' perceptions of teacher leadership. The scale consists of three sub-dimensions (institutional development, professional development, and collaboration with colleagues) and 25 items. The scale is in 5-point Likert form and takes values between "always (5)" and "never (1)". The scale evaluates teacher leadership roles in terms of perception and expectations. In this study, only teacher leadership roles were evaluated in terms of perception. The internal consistency coefficient of the scale was calculated as .95. The internal consistency coefficient of the scale was found to be .94 . The sub-dimensions were .89 for "organisational development", 90 for "professional development", and .81 for "collaboration with colleagues". The construct validity was tested by Confirmatory Factor Analysis (CFA). The results of DFA; $X^{2}=608.14, \mathrm{df}=249(\mathrm{p}=.00), \mathrm{X}^{2} / \mathrm{df}=2.44, \mathrm{GFI}=$ $.82, \mathrm{AGFI}=.78, \mathrm{RMSEA}=.063, \mathrm{NFI}=.96, \mathrm{SRMR}=.066, \mathrm{CFI}=.98$ were determined to be within the acceptable value limits (Çokluk, Şekercioğlu, \& Büyüköztürk 2012; Meydan \& Şeşen, 2011; Schermelleh-Engel, Moosbrugger, \& Hans, 2003).

\section{Analysis of Data}

The missing or erroneous data and the data with extreme values (according to $Z$ values) were analysed by statistical programs. Descriptive statistics (frequency, percentage, arithmetic mean, standard deviation, correlation coefficients) and nonparametric tests (Kruskal Wallis test and Mann Whitney $\mathrm{U}$ test) were used in the data analysis. Additionally, the suitability of the data for normal distribution (kurtosis, skewness, and relative multivariate kurtosis coefficients) and whether there was a problem with multicollinearity (TV and VIF values) were checked, and the predictive relationships between the variables were examined by simple linear regression analysis.

\section{FINDINGS}

The arithmetic means and standard deviation values related to organisational support and teacher leadership are given in Table 2 below. 
Table 2. Teachers' perception level of organisational support and teacher leadership

\begin{tabular}{lcc}
\hline Variables & $\overline{\mathrm{x}}$ & S.D. \\
\hline Organisational support & 5.76 & .95 \\
Teacher leadership (Overall) & 4.22 & .53 \\
Institutional development & 3.90 & .72 \\
Professional development & 4.45 & .48 \\
Collaboration with colleagues & 4.31 & .58 \\
\hline
\end{tabular}

When Table 2 examined, it is seen that teachers' perceptions of organisational support $(\bar{x}=5.76)$ are high (in the "I agree" option), and teachers' perceptions of teacher leadership ( $\bar{x}=4.22$ ) are also high (in the "always" option). Besides, when the subdimensions were examined, the highest score was observed within professional development $(\bar{x}=4.45)$ while the lowest within institutional development $(\bar{x}=3.90)$.

The Mann-Whitney $U$ test results on the teachers' perception of organisational support and leadership according to gender are given in Table 3 below.

Table 3. Mann Whitney $U$ test results of teachers' perceptions of organisational support and teacher leadership according to gender

\begin{tabular}{|c|c|c|c|c|c|c|}
\hline \multirow[t]{2}{*}{ Variables } & \multicolumn{2}{|c|}{ Mean Ranks } & \multicolumn{2}{|c|}{ Sum of Ranks } & \multirow[t]{2}{*}{$U$} & \multirow[t]{2}{*}{$p$} \\
\hline & $\begin{array}{l}\text { Female } \\
n=121\end{array}$ & $\begin{array}{c}\text { Male } \\
n=146\end{array}$ & $\begin{array}{l}\text { Female } \\
n=121\end{array}$ & $\begin{array}{c}\text { Male } \\
n=146\end{array}$ & & \\
\hline Organisational support & 144.74 & 125.10 & 17513.50 & 18262.50 & 7533.50 & .038 \\
\hline Teacher leadership & 139.40 & 129.52 & 16867.00 & 18910.50 & 8179.50 & .298 \\
\hline Institutional development & 137.21 & 131.34 & 16603.00 & 19165.00 & 8444.00 & .535 \\
\hline Professional development & 141.61 & 127.69 & 17135.00 & 18643.00 & 7912.00 & .141 \\
\hline Collaboration with colleagues & 135.59 & 132.68 & 16406.00 & 19372.00 & 8641.00 & .758 \\
\hline
\end{tabular}

When Table 3 is examined, teachers' perceptions of organisational support $(U=7533.50 ; p<.05)$ show a significant difference according to gender. Accordingly, it can be stated that female teachers have more perception of organisational support than male teachers. Besides, it can be seen from Table 3 that the perceptions of teachers regarding teacher leadership and the sub-dimensions of institutional development, professional development, and collaboration with colleagues are not significantly different according to gender. In other words, male and female teachers' perceptions of their leadership roles are similar.

The Kruskal Wallis tests result on the teachers' perception of organisational support and leadership according to age are given in Table 4 below.

Table 4. Kruskal Wallis test results of teachers' perceptions of organisational support and teacher leadership according to age

\begin{tabular}{|c|c|c|c|c|c|c|c|c|}
\hline \multirow[t]{3}{*}{ Variable } & \multicolumn{4}{|c|}{ Mean ranks } & \multirow[t]{3}{*}{$d f$} & \multirow[t]{3}{*}{$X^{2}$} & \multirow[t]{3}{*}{$p$} & \multirow{3}{*}{$\begin{array}{l}\text { Significant } \\
\text { difference }\end{array}$} \\
\hline & A & $\mathrm{B}$ & $\mathrm{C}$ & $\mathrm{D}$ & & & & \\
\hline & $n=23$ & $n=101$ & $n=114$ & $n=52$ & & & & \\
\hline Organisational support & 167.52 & 150.46 & 149.75 & 116.82 & 3 & 8.320 & .040 & $A-D, B-D, C-D$ \\
\hline Teacher leadership & 135.17 & 144.09 & 148.33 & 146.59 & & .517 & .915 & \\
\hline Institutional development & 148.46 & 143.98 & 146.64 & 144.66 & & .088 & .993 & \\
\hline Professional development & 132.48 & 148.31 & 146.34 & 143.96 & & .703 & .872 & \\
\hline Collaboration with colleagues & 118.00 & 139.04 & 154.18 & 151.18 & & 4.610 & .203 & \\
\hline
\end{tabular}

A: 20-30 age $\quad$ B: 21-40 age C: 41-50 age $\quad$ D: 51 and overage

When Table 4 is examined, it is seen that teachers' perceptions of organisational support differ significantly according to the age variable $\left[X^{2}(3)=8.320 ; p<.05\right]$. Mann Whitney $U$ test was applied to determine which groups caused this difference. Accordingly, it was determined that teachers aged 51 and over had lower organisational support perceptions than teachers in the 20-30, 21-40, and 41-50 age groups. Besides, it can be seen from Table 4 above that the perceptions of teachers regarding teacher leadership and the sub-dimensions of institutional development, professional development, and collaboration with colleagues are not significantly different according to age.

The Kruskal Wallis test results on the teachers' perception of organisational support and leadership according to professional seniority are given in Table 5 below. 
Table 5. Kruskal Wallis test results of teachers' perceptions of organisational support and teacher leadership according to professional seniority

\begin{tabular}{|c|c|c|c|c|c|c|c|}
\hline \multirow[t]{2}{*}{ Variables } & \multicolumn{3}{|c|}{ Mean ranks } & \multirow[b]{2}{*}{$d f$} & \multirow[b]{2}{*}{$X^{2}$} & \multirow[b]{2}{*}{$p$} & \multirow[b]{2}{*}{ Significant difference } \\
\hline & $\begin{array}{c}\text { A } \\
n=59\end{array}$ & $\begin{array}{c}\mathrm{B} \\
n=113\end{array}$ & $\begin{array}{c}C \\
n=101\end{array}$ & & & & \\
\hline Organisational support & 135.70 & 144.85 & 128.97 & 2 & 2.180 & .336 & - \\
\hline Teacher leadership & 119.55 & 145.42 & 137.78 & & 4.181 & .124 & - \\
\hline Institutional development & 126.98 & 142.96 & 136.18 & & 1.610 & .447 & - \\
\hline Professional development & 122.28 & 145.48 & 136.11 & & 3.398 & .183 & - \\
\hline Collaboration with colleagues & 113.53 & 142.97 & 144.03 & & 6.777 & .034 & $A-B, A-C$ \\
\hline
\end{tabular}

A: 0-10 years B: 11-20 years C: 21 years and over

When Table 5 is examined, it is seen that teachers' perceptions of organisational support do not differ significantly according to professional seniority. Similarly, it can be seen from Table 5 that the perceptions of teachers regarding teacher leadership and the sub-dimensions of institutional development and professional development are not significantly different according to professional seniority. However, teachers' perceptions of collaboration with colleagues differ significantly according to the seniority variable $\left[\mathrm{X}^{2}{ }_{(2)}=6.777 ; \mathrm{p}<.05\right]$. Mann-Whitney $\mathrm{U}$ test was used to determine the difference between groups. Accordingly, it was determined that teachers with seniority of 0-10 years had a lower perception of collaboration with colleagues than teachers between 11-20 years and over 21 years.

The Kruskal Wallis test results on the teachers' perception of organisational support and leadership according to educational status are given in Table 6 below.

Table 6. Kruskal Wallis test results of teachers' perceptions of organisational support and teacher leadership according to educational status

\begin{tabular}{|c|c|c|c|c|c|c|c|}
\hline \multirow[t]{2}{*}{ Variables } & \multicolumn{3}{|c|}{ Mean ranks } & \multirow[b]{2}{*}{$d f$} & \multirow[b]{2}{*}{$X^{2}$} & \multirow[b]{2}{*}{$p$} & \multirow[b]{2}{*}{$\begin{array}{l}\text { Significant } \\
\text { difference }\end{array}$} \\
\hline & $\begin{array}{c}\text { A } \\
n=7\end{array}$ & $\begin{array}{c}\text { B } \\
n=219\end{array}$ & $\begin{array}{c}\text { C } \\
n=46\end{array}$ & & & & \\
\hline Organisational support & 91.21 & 138.20 & 135.32 & 2 & 2.434 & .296 & - \\
\hline Teacher leadership & 72.50 & 137.56 & 141.18 & & 4.842 & .089 & - \\
\hline Institutional development & 77.64 & 136.31 & 146.38 & & 4.659 & .097 & - \\
\hline Professional development & 89.50 & 137.56 & 146.38 & & 2.594 & .273 & - \\
\hline Collaboration with colleagues & 64.71 & 139.09 & 135.09 & & 6.188 & .045 & $A-B, A-C$ \\
\hline
\end{tabular}

A: Associate degree B: Undergraduate C: Graduate

When Table 6 is examined, it is seen that teachers' perceptions of organisational support do not differ significantly according to their educational status. Similarly, it can be seen from Table 6 that the perceptions of teachers regarding teacher leadership and the sub-dimensions of institutional development and professional development are not significantly different according to the educational status. However, teachers' perceptions of collaboration with colleagues differ significantly according to the educational status. $\left[X^{2}{ }_{(2)}=6.188 ; p<.05\right]$. Mann-Whitney $U$ test was used to determine the difference between groups. Accordingly, it was determined that teachers with associate degrees have a lower perception of collaboration with colleagues than teachers with undergraduate and graduate degrees.

The Kruskal Wallis test results on the teachers' perception of organisational support and leadership according to high school type are given in Table 7 below.

Table 7. Kruskal Wallis test results of teachers' perceptions of organisational support and teacher leadership according to the high school type

\begin{tabular}{|c|c|c|c|c|c|c|c|}
\hline \multirow[t]{2}{*}{ Variables } & \multicolumn{3}{|c|}{ Mean ranks } & \multirow[b]{2}{*}{$d f$} & \multirow[b]{2}{*}{$x^{2}$} & \multirow[b]{2}{*}{$p$} & \multirow[b]{2}{*}{$\begin{array}{l}\text { Significant } \\
\text { difference }\end{array}$} \\
\hline & $\begin{array}{c}\text { A } \\
n=121\end{array}$ & $\begin{array}{c}\text { B } \\
n=145\end{array}$ & $\begin{array}{c}C \\
n=32\end{array}$ & & & & \\
\hline Organisational support & 161.21 & 146.24 & 119.97 & 2 & 6.206 & .236 & $A-C$ \\
\hline Teacher leadership & 158.28 & 143.09 & 145.34 & & .344 & .344 & - \\
\hline Institutional development & 159.38 & 141.38 & 148.94 & & 2.888 & .834 & - \\
\hline Professional development & 153.07 & 147.37 & 145.66 & & .364 & .408 & - \\
\hline Collaboration with colleagues & 157.11 & 145.56 & 138.56 & & 1.793 & .045 & - \\
\hline
\end{tabular}

A: Teachers working in high schools that accept students without an examination

B: Teachers working in high schools that accept students with an examination (LGS-High School Entrance Exam)

C: Teachers working in high schools that accept students with a special talent examination

When Table 7 is examined, teachers' perceptions of organisational support differ significantly according to the high school type $\left[X^{2}{ }_{(2)}=6.206 ; p<.05\right]$. Mann-Whitney $U$ test was used to determine the difference between groups. Similarly, it was observed that teachers working in high schools that accept students without examination had a higher perception of 
organisational support than teachers working in high schools that accept students with aptitude tests. Besides, it can be seen from Table 7 that the perceptions of teachers regarding teacher leadership and the sub-dimensions of institutional development, professional development, and collaboration with colleagues are not significantly different according to the high school type.

Correlation analysis results regarding organisational support and teacher leadership are presented in Table 8 below.

Table 8. Correlation coefficients for organisational support and teacher leadership

\begin{tabular}{|c|c|c|c|c|c|}
\hline Variables & 1 & 2 & 3 & 4 & 5 \\
\hline 1. Organisational support & - & $.444 * *$ & $.434 * *$ & $.391 * *$ & $318^{* *}$ \\
\hline 2. Teacher leadership & & - & $.924^{* *}$ & $.892 * *$ & $.816^{* *}$ \\
\hline 3. Institutional development & & & - & $.692 * *$ & $.671 * *$ \\
\hline 4. Professional development & & & & - & $646 * *$ \\
\hline 5. Collaboration with colleagues & & & & - & - \\
\hline
\end{tabular}

When Table 8 is examined, there is a moderate, positively significant relationship $(r=.444, p<.01)$ between teachers' perceptions of organisational support and teacher leadership. In addition, there is a moderate, positively significant relationship between organisational support and institutional development $(r=434, p<.01)$; professional development $(r=.391, p<.01)$, collaboration with colleagues, and organisational support $(r=318, p<.01)$. Accordingly, it can be stated that if teachers' perceptions of organisational support increase, their perceptions of teacher leadership towards institutional development, professional development, and collaboration with colleagues will increase.

The simple linear regression analysis results for predicting the sub-dimensions of teacher leadership are presented in Table 9 below.

Table 9. Simple linear regression analysis for predicting the sub-dimensions of teacher leadership $(n=298)$

\begin{tabular}{lccccccccc}
\hline & \multicolumn{3}{c}{ Variable } & \multicolumn{3}{c}{ Institutional development $^{a}$} & \multicolumn{2}{c}{ Professional development $^{b}$} & \multicolumn{3}{c}{ Collaboration with colleagues $^{c}$} \\
\cline { 2 - 9 } & $b$ & $t$ & $p$ & $b$ & $t$ & $p$ & $b$ & $t$ & $p$ \\
\hline Constant & - & 8.809 & .000 & - & 20.714 & .000 & - & 16.322 & .000 \\
Organisational support & .434 & 8.295 & .000 & .391 & 7.299 & .000 & .318 & 5.780 & .000 \\
\hline
\end{tabular}

${ }^{a} R=.434, R^{2}=.189, F_{(1-296)}=68.812, p=.000$

${ }^{b} R=.391, R^{2}=.153, F_{(1-296)}=53.280, p=.000$

${ }^{c} R=.318, R^{2}=.101, F_{(1-296)}=33.408, p=.000$

When Table 9 is examined, significant relationships are observed between organisational support and institutional development $\left(R=.434, R^{2},=.189\right)$, professional development $\left(R=.391, R^{2}=.153\right)$, and collaboration with colleagues $(R=.391$, $\left.R^{2}=.153\right)$. It is seen that organisational support is a significant predictor of institutional development $(F(1-296)=68.812, \mathrm{p}<.05)$, professional development $\left(F_{(1-296)}=53.280, p<.05\right)$, and collaboration with colleagues $\left(F_{(1-296)}=33.408, p<.05\right)$. Organisational support explains $19 \%, 15 \%$, and $10 \%$ of institutional development, professional development, and collaboration with colleagues, respectively.

\section{DISCUSSION and RECOMMENDATIONS}

We found that the participant teachers had a high level of organisational support perception. The findings of the research conducted by Argon and Yılmaz (2019), Argon and Ekinci (2017), Eğriboyun (2013), Geçer (2015), Nartgün and Kalay (2014), Terzi and Çelik (2016) show consistency with this finding. According to the research results, it can be said that teachers' perceptions of teacher leadership are high. In other words, it can be stated that teachers create a positive classroom climate by planning activities to improve student learning in the classroom and aim to develop a learning culture at school by working with their colleagues. This finding is similar to the findings of studies conducted by Aslan, Çalık, and Er (2019), Beycioğlu and Aslan (2012), Kılınç and Recepoğlu (2013), Öztürk and Şahin (2017), Yılmaz (2018) and Yılmaz, Oğuz, and Altınkurt (2017). It was determined that the teachers had high professional development perceptions and low institutional development perceptions. This finding is similar to the research findings of Beycioğlu and Aslan (2012), Savaş (2016), Yılmaz, Oğuz, and Altınkurt (2017) and Yılmaz (2018). According to the research findings, teacher leadership is considered very important in professional development. Accordingly, teachers consider behaviours including the use of technology, learning and using different teaching methods, and following the developments in their field are important in terms of educational quality. However, despite their efforts to increase the quality of education in the classroom, it can be stated that their participation in studies based on school development is weaker. According to Balyer (2016), teacher leaders are always at the forefront in terms of participation in the decisions taken at school, the suggestions they present at meetings, and the planning of social activities at the school. In summary, it can be stated that the institutional development dimension of teacher leadership is at a lower level than professional development and colleague cooperation since it expresses that teachers have multidimensional characteristics.

Teachers' perceptions of organisational support show a significant difference according to gender. Accordingly, female teachers have a higher perception of organisational support than male teachers. Different results have been reached in the 
studies conducted in the literature. In the studies conducted by Eğiriboyun (2013), Argon and Ekinci (2017), Büyükgöze and Kavak (2017), Turan-Dallı (2018), and Uğur (2017), teachers' perceptions of organisational support do not differ significantly according to gender. However, in the studies conducted by Gül (2010) and Meriç, Öztürk Çiftçi, and Yurtal (2019), teachers' perceptions of organisational support differ significantly according to gender, and it was found that male teachers' perceptions of organisational support were higher compared to female teachers. Nayır (2011) found that male teachers' perceptions of management support were higher than female teachers. On the other hand, a meta-analysis study by Rhoades and Eisenberger (2002) found a weak and significant relationship between gender and the perception of organisational support. In this context, some findings are similar or different from the findings of this study in the literature. These differences are thought to stem from the difference in the sample group of the study. Eğiriboyun (2013), Büyükgöze and Kavak (2017), Turan-Dallı (2018), and Gül (2010) conducted their studies on a secondary education sample; Argon and Ekinci (2017), Meriç, Öztürk Çiftçi, and Yurtal (2019) Uğur (2017), and Nayır (2011) conducted their studies on the primary school sample. This research was conducted on a secondary education sample consisting of five high school types (Anatolian High School, Vocational and Technical Anatolian High School, Fine Arts High School, Sports High School, Science High School). In this respect, female teachers' reason for having a higher perception of organisational support than male teachers may be the difference in the sample group.

We observed that the perceptions of teachers regarding teacher leadership and the sub-dimensions of institutional development, professional development, and collaboration with colleagues did not significantly differ according to gender. In other words, the teacher leadership perceptions of male and female teachers are at a similar level. This finding and the research findings of Ovacıklı (2018), Kılınç and Recepoğlu (2013), Yılmaz, Oğuz and Altınkurt (2016), Beycioğlu and Aslan (2012), and Yılmaz (2018) overlap. On the other hand, it is stated in the literature that the behaviours of female and male employees may differ within the framework of the concept of "gender-role spillover", which means the transfer of gender-based behavioural expectations to the workplace (Gutek, \& Morasch, 1982). A meta-analysis study conducted by Eagly and Johnson (1990) revealed that leadership styles differ according to gender. They attributed this situation to expectations, behaviour, and roles that differ according to gender. However, the present study differs in terms of the sample. The sample of Eagly and Johnson's (1990) study is probably the managers chosen by their institutions according to certain criteria. In contrast, the present study is formed by teachers and focuses on teachers' perceptions of how much they put themselves in leadership positions and to what extent they display leadership roles. Unlike administrators, it can be said that conditions of entering the teaching profession do not differ according to gender, reducing the possibility of the leadership roles differing by gender.

We found that teachers' perceptions of organisational support differed significantly according to the age variable. Accordingly, it was observed that teachers in the age group 51 and over had a lower perception of organisational support than teachers in the 20-30, 21-40, and 41-50 age group. In other words, it can be stated that as the age of teachers increases, their perceptions of organisational support decrease. This finding coincides with the research findings conducted by Derinbay (2011) and Yoshimura (2003). In Derinbay's (2011) research, teachers' perceptions of organisational support, administrative support and justice were higher in younger age group teachers. According to Yoshimura (2003), the organisational support perceptions of older employees are lower than those of younger employees. It can be stated that young teachers need to learn more about the school's functioning and organisational culture and be guided and informed more, and thus they receive more organisational support. It can be said that teachers need organisational support less in the process as their professional experience and knowledge increase with age. The literature has reached different results on whether teachers' perceptions of organisational support differ significantly according to the age variable. In the studies conducted by Eğriboyun (2013), Erkol (2015), Geçer (2015), and Uğur (2017), it was determined that teachers' perceptions of organisational support did not differ significantly between the age variable. This difference in research results may be because the studies were conducted at different education levels and with different sample sizes.

Teachers' perceptions of teacher leadership in general and sub-dimensions of institutional development, professional development, and peer collaboration do not differ significantly by age. In other words, teacher leadership perceptions of teachers from different age groups are similar. Teacher leadership is an understanding based on the development of skills that will contribute to the professional learning skills of teachers of all age groups in the institution, colleague relations, and the school's development. Therefore, it can be stated that teachers' perceptions of teacher leadership are similar regardless of age. In the literature, there are limited numbers of empirical studies examining teachers' perceptions of teacher leadership according to the age variable, and different findings have emerged in the studies. In the study conducted by Akdoğan (2021), there are significant differences in teachers' perceptions of teacher leadership. The perceptions of the teachers aged 41-50 and those aged 51 and over are higher than those in the 20-30 age range. The study conducted by Gülbahar (2017) determined that the 36-40 age group teachers' perceptions of teacher leadership in the professional development dimension were different and higher than the 26-30 age group teachers' perceptions of teacher leadership. The study conducted by Önder and Küpeli (2018) determined that teachers aged 30 and younger had higher perceptions of teacher leadership. The study conducted by Kılınç and Recepoğlu (2013), determined that teachers' perceptions of teacher leadership did not differ significantly in terms of professional development and cooperation with colleagues according to the age variable. Still, there was a significant difference in the dimension of institutional development. This difference may be related to the studies being conducted at different education levels and with different sample sizes. 
We concluded that teachers' perceptions of organisational support did not differ significantly according to seniority. In other words, organisational support perceptions of teachers with different seniority are similar. This finding corresponds to the findings of the studies conducted by Erkol (2015), Eğriboyun (2013), Gül (2010), Nartgün and Kalay (2014), Terzi and Çelik (2016), and Turan-Dallı (2018). In this study, teachers' perceptions of teacher leadership's professional development and institutional development dimensions do not differ significantly according to the seniority variable; on the other hand, their perceptions regarding the collaboration with colleagues dimension differ significantly according to the seniority variable. We found that teachers with a seniority of 0-10 years have a lower perception of peer collaboration than teachers with a seniority of 11-20 years and over 21 years. This may be because teachers develop cooperation and solidarity among themselves in the process. It is natural for teachers to increase their professional knowledge and experience depending on their professional seniority. Thus, the desire of senior teachers to share their professional knowledge and experience with their colleagues, who are relatively less senior than themselves, may have led to higher perceptions of colleague cooperation. Some studies in the literature show similarities or differences with these research findings. In the studies conducted by Yılmaz (2018) and Yılmaz, Oğuz, and Altınkurt (2017), no significant difference was found between perceptions of teacher leadership according to professional seniority. The study conducted by Gülbahar (2017) determined that the professional development perceptions of teachers with 11-15 and 1620 years of seniority were significantly higher than the professional development perceptions of teachers with 6-10 years of seniority. In the study conducted by Kılınç and Recepoğlu (2013), it was determined that less experienced teachers with 1-5 years of seniority had higher perceptions of the colleague cooperation dimension of teacher leadership. The study conducted by Beycioğlu and Aslan (2012) determined that although all sub-dimensions of teacher leadership differ significantly according to the variable of professional seniority, the perceptions of teachers with a seniority of 21 years and above are higher than the perceptions of other teachers. This difference may be because the studies were conducted at different educational levels.

We determined that teachers' perceptions of organisational support did not differ significantly according to educational status. In other words, the perceptions of organisational support of teachers with different education levels are similar. This finding of the study overlaps with the findings of the studies conducted by Büyükgöze and Kavak (2017), Kılınç (2019), Meriç, Öztürk Çiftçi and Yurtal (2019), Nartgün and Kalay (2014), and Uğur (2017). We observed that teachers' perceptions of teacher leadership in general and sub-dimensions of institutional development and professional development did not show a significant difference according to the variable of educational status. However, teachers' perceptions of the collaboration with colleagues dimension of teacher leadership differ significantly according to educational status. Accordingly, it has been determined that teachers with an associate degree have a lower perception of colleague cooperation than teachers with undergraduate and graduate degrees. Accordingly, it can be stated that as the level of education increases, cooperation and solidarity among teachers increase. This may be because teachers with associate degrees go through a shorter training program and consequently develop less interaction and cooperation. Studies by Beycioğlu (2009), Yılmaz (2018), and Dinçer (2017) reveal that teachers' perceptions of teacher leadership do not differ significantly according to the variable of educational status.

We determined that teachers' perceptions of organisational support differed significantly according to the high school's type variable. It has been observed that teachers working in schools that accept students without examination have a higher perception of organisational support than teachers working in schools that accept students with aptitude tests. Considering that teachers working in schools that accept students without exams, deal with disciplinary problems, administrative affairs, and work in more crowded classrooms, it may seem natural that they need more organisational support. The schools that accept students with the talent exam are the Fine Arts High School and the Sports High School. Unlike other schools, in high schools that accept students with aptitude tests, it is very important to create the necessary physical environments for teachers to reach the course's objectives and develop the skills of their students. For this reason, the organisational support of teachers in these schools becomes more important.

We found that teachers' perceptions of overall teacher leadership and institutional development, professional development and collaboration with colleagues did not differ significantly according to the variable of high school type. In other words, teacher leadership perceptions of teachers working in high schools that accept students differently are similar. In the studies conducted in the literature, teachers' perceptions of teacher leadership were examined from different angles according to the high school type variable. Accordingly, in the study conducted by Gül (2010), it was determined that the organisational support perceptions of teachers in private high schools were higher than those in public high schools. In the study conducted by Geçer (2015), it is stated that teachers working in Anatolian High Schools have higher organisational support perceptions than other types of high schools. The study conducted by Önder and Küpeli (2013) revealed that teachers' perceptions of teacher leadership differed significantly in all dimensions according to the school type. They also stated that the perceptions of teacher leadership of the participants working in science and social sciences high schools were higher than those working in other types of high schools. Similarly, Savaş (2016) determined that teachers' perceptions of the institutional development dimension of teacher leadership differed significantly according to the type of school, and teachers working in academic high schools had higher perceptions of teacher leadership than vocational high school teachers. In this study, the teacher leadership perceptions of teachers working in different high school types are similar (which may be related to sample diversity and size).

There is a moderate, positive, and significant relationship between teachers' perceptions of organisational support and teacher leadership. In addition, there are moderately positive and significant relationships between institutional development, professional development, collaboration with colleagues, and organisational support. Accordingly, it can be stated that if 
teachers' perceptions of organisational support increase, teachers' perceptions of teacher leadership's dimensions of institutional development, professional development, and collaboration with colleagues will increase. It can be said that with perceived organisational support, teachers will make more effort to achieve the school's goals, and they will be better motivated to do their work. According to Tanrıverdi and Kılıç (2016), organisational support has a reducing effect on the level of alienation of the individual from the organisation. As organisational support increases, job satisfaction, emotional commitment, and performance increase (Rhoades \& Eisenberger, 2002). According to Berg and Zoellick (2019), one of the most important elements of teacher leadership is the perception of support. It is necessary to provide opportunities for teachers to develop their professional development and leadership skills and support teachers in working with and getting help from school principals. In the research conducted by Araşkal and Kılınç (2019), it was determined that the inadequacy of administrative support is a problem faced by teacher leaders. However, teacher leaders can take more responsibility and risk when they get the support of school principals (Araşkal \& Kılınç, 2019). According to Can (2006), school principals should first create an environment that encourages leadership and provides and supports teachers with self-development opportunities to develop teacher leaders.

We determined that organisational support and teacher leadership were significant predictors of institutional development, professional development, and collaboration with colleagues. Accordingly, organisational support explains $18 \%$ of organisational development, $15 \%$ professional development, and $10 \%$ collaboration with colleagues. In the light of these findings, it can be stated that organisational support affects teacher leadership. Teachers, who feel that they are valued and cared for by the organisation, will strive to improve their teaching activities to increase student learning at school and influence and lead their colleagues in this regard. According to Öztürk (2017), creating a supportive school culture by encouraging teacher leadership can make significant contributions to the emergence and development of teacher leadership. In this direction, some studies can be done to create a culture of teacher leadership at school. For example, greater participation in teacher leadership can be achieved by creating opportunities for teachers to participate in decision-making processes and support professional development opportunities. In short, school administrations should develop a positive relationship with teachers based on cooperation. According to Harris and Muijs (2005), teachers will engage in more activities when they work together in solidarity and cooperation with their colleagues and are supported organisationally. In this way, systematic opportunities can be provided for teachers to cooperate with their colleagues. Thus, collective learning increases and teacher leaders can better contribute to the professional development of their colleagues (Rutherford, 2006). As a result, it is thought that teacher leadership can be improved by strengthening organisational learning in schools, supporting teachers to create a positive school climate, revealing leadership skills, and creating a culture of learning together.

This study examined the relationship between organisational support and teacher leadership perceptions of teachers working in different high school types. In this context, studies could be conducted using different variables at different education levels to contribute to the field. Furthermore, we argue that there is a need for studies to determine the factors that will increase the perception of organisational support, examine the results of organisational support, and the factors that will affect teacher leadership.

\section{Declaration of Conflicting Interests}

The author(s) declared no potential conflicts of interest concerning this article's research, authorship, and/or publication.

\section{Funding}

The author(s) received no financial support for this article's research, author-ship, and/or publication.

\section{Statements of publication ethics}

We hereby declare that the study has no ethical issues and that research and publication ethics have been carefully observed.

\section{Ethics Committee Approval Information}

In this study, all rules stated to be followed within the scope of "Higher Education Institutions Scientific Research and Publication Ethics Directive" were followed. The second part of the directive is "contradictory to the Scientific Research and Publication Ethics Actions" title was not carried out in any of the actions specified below.

Ethics committee permission information:

Name of the institution conducting the ethical assessment = Hatay Mustafa Kemal University

Social and Humanities Scientific Research and Publication Ethics Board

Date of the ethical assessment decision $=12.08 .2020$

Ethics assessment document issue number $=\mathrm{E} .35803$ 


\section{REFERENCES}

Akdoğan, A. (2021). Öğretmenlerin özgeci davranışları ile öğretmen liderliğine yönelik algı ve beklentileri arasındaki ilişkisinin incelenmesi [Unpublished master's thesis]. Karamanoğlu Mehmetbey Üniversitesi.

Akın, M. (2008). Örgütsel destek, sosyal destek ve iş/aile çatışmalarının yaşam tatmini üzerindeki etkileri. Erciyes Üniversitesi Sosyal Bilimler Enstitüsü Dergisi, 25(1), 141- 170.

Araşkal, S., \& Kılınç, A. Ç. (2019). Öğretmen liderliğini etkileyen faktörlerin incelenmesi: Nitel bir araştırma. Kuram ve Uygulamada Eğitim Yönetimi, 25(3), 419-468.

Argon, T., \& Ekinci, S (2017). Teacher views on organizational support and psychological contract violation. Journal of Education and Practice, $8(2), 44-55$.

Argon, T., \& Yılmaz, Ö. (2019). Öğretmenlerin öğretim duyguları ile örgütsel destek algıları arasındaki ilişki. 14. Uluslararası Eğitim Yönetimi Kongresi Tam Metin Bildiri Kitabı. https://www.pegem.net/dosyalar/dokuman/ICES-UEBK-TamMetin.pdf

Aslan, H., Çalık, T., \& Er, E. (2019). illkokul öğretmenlerinin öğretmen liderliği ve politik beceri algılarının incelenmesi. ilköğretim Online, 18(3), 1087-1098. doi:10.17051/ilkonline.2019.610689

Balyer, A. (2016). Öğretmen liderler: Öğretmen algıları üzerine nitel bir araştırma. illköğretim Online, 15(2), 391-407.

Berg, J. H., \& Zoellick, B. (2019). Teacher leadership: Toward a new conceptual framework. Journal of Professional Capital and Community, 4(1), 2-14. https://doi.org/10.1108/JPCC-06-2018-0017

Beycioğlu, K. (2009). Illköğretim okullarında öğretmenlerin sergiledikleri liderlik rollerine ilişkin bir değerlendirme (Hatay ili örneği) [Unpublished doctoral dissertation]. İnönü University.

Beycioğlu, K., \& Aslan, B. (2012). Öğretmen ve yöneticilerin öğretmen liderliğine ilişkin görüşleri: Bir karma yöntem çalışması. Kuram ve Uygulamada Ĕgitim Yönetimi, 18(2), 191-223.

Bishop, J. (2000). Commitment and employee outcomes in a team environment. Journal of Management, 26(6), 1113-1132. https://doi.org/10.1177/014920630002600603

Büyükgöze, H., \& Kavak, Y. (2017). Algılanan örgütsel destek ve pozitif psikolojik sermaye ilişkisi: Lise öğretmenleri örnekleminde bir inceleme. Kuram ve Uygulamada Eğitim Yönetimi, 23(1), 1-32.

Büyüköztürk, Ş., Çakmak, E. K., Akgün, Ö. E., Karadeniz, Ş. \& Demirel, F. (2010). Bilimsel araştırma yöntemleri (5. Bs.), Ankara: Pegem Yayıncılık.

Can, N. (2006). Öğretmen liderliğinin geliştirilmesinde müdürün rol ve stratejileri. Erciyes Üniversitesi Sosyal Bilimler Enstitüsü Dergisi, 21(2), 349-363.

Can, N. (2007). Öğretmen liderliği becerileri ve bu becerilerin gerçekleştirilme düzeyi. Erciyes Üniversitesi Sosyal Bilimler Enstitüsü Dergisi, 22(1), 263-288.

Chinomona. R., \& Sandada, M. (2014). Organisational support and its influence on teachers' job satisfaction and job performance in Limpopo Province of South Africa. Mediterranean Journal of Social Sciences, 5(9), 208-214. doi: 10.5901/mjss.2014.v5n9p208

Cropanzano, R. (1999). Organizational politics and organizational support as predictors of work attitudes, job performance, and organizational citizenship behavior. Journal of Organizational Behavior, 20(2), 159-174. https://doi.org/10.1002/(SICI)10991379(199903)20:2<159::AID-JOB881>3.0.CO;2-7

Çokluk, Ö. Şekericioğlu, G., \& Büyüköztük, Ş. (2012). Sosyal bilimler için çok değişkenli istatsitik spss ve lisrel uygulamaları. Ankara: Pegem Yayıncilık.

Derinbay, D. (2011). Ilköğretim okullarında görev yapan öğretmenlerin algıladıkları örgütsel destek düzeyleri (Yayınlanmamış yüksek lisans tezi). Pamukkale Üniversitesi, Manisa.

Dinçer, K. (2017). Ilkokullarda örgütsel yaratıcılık davranışları ile öğretmen liderliği arasındaki ilişki [Unpublished master's thesis]. Dumlupınar University.

Eagly, A. H., \& Johnson, B. T. (1990). Gender and leadership style: A Meta-Analysis. Psychological Bulletin, 108(2), 233-256.

Eğriboyun, D. (2013). Ortaöğretim okullarında görev yapan yönetici ve öğretmenlerin örgütsel güven ve örgütsel destek algıları arasındaki ilişki. Kafkas Üniversitesi Sosyal Bilimler Enstitüsü Dergisi, 12, 17-43.

Gülbahar, B. (2017). Investigation of perceptions regarding teacher leadership among secondary school teachers in Turkey. Journal of Education and Training Studies, 5(2), 111-119.

Eker, S. (2019). Okul müdürünün liderliğinin ve öğretmen liderliğinin öğrenci başarısı üzerindeki etkileri [Unpublished master's thesis]. Kırıkkale University.

Eisenberger, R., Huntington, R., Hutchinson, S., \& Sowa, D. (1986). Perceived organizational support. Journal of Applied Psychology, 71, 500507. https://doi.org/10.1037/0021-9010.71.3.500

Eisenberger, R., \& Stinglhamber, F. (2011). Perceived organizational support: Fostering enthusiastic and productive employees. American Psychological Association. doi:10.1037/12318-000

Erdogan, B., \& Enders, J. (2007). Support from the top: Supervisors' perceived organizational support as a moderator of leader-member exchange to satisfaction and performance relationships. Journal of Applied Psychology, 92(2), 321-330. doi: 10.1037/00219010.92.2.321

Erkol, H. (2015). Ortaöğretim öğretmenlerinin algıladıkları örgütsel desteğin bireysel özelliklerine göre incelenmesi. Anadolu Eğitim Liderliği ve Öğretim Dergisi, 3(1), 1-17.

Geçer, A. (2015). Liselerde çalışan öğretmenlerin kayırmacılık ve örgütsel destek algı düzeyleri (Muğla ili örneği) [Unpublished master's thesis]. Muğla Sıtkı Koçman University. 
Gökyer, N., \& Türkoğlu, í. (2018). Liselerde görev yapan öğretmenlerin örgütsel destek algıları ile örgütsel sinizm tutumları arasındaki ilişki. Education and Science, 43(196), 317-340. https://doi.org/10.15390/EB.2018.7440

Gutek, B. A., \& Morasch, B. (1982). Sex-ratios, sex-role spillover, and sexual harassment of women at work. Journal of Social Issues, 38(4), 5574. https://doi.org/10.1111/j.1540-4560.1982.tb01910.x

Gül, A. L. (2010). Lise öğretmenlerinin algılarına göre örgütsel destek (Ankara ili örneği) [Unpublished doctoral dissertation]. Hacettepe University.

Harris, A., \& Muijs, D. (2005). Improving schools through teacher leadership. Open University Press.

Hutchison, S. (1997). A path model of perceived organizational support. Journal of Social Behavior and Personality, 12, $159-174$.

İnanır, B. (2020). Öğretmenlerin işle bütünleşme düzeyleri ile okul iklimi ve öğretmen liderliği arasındaki ilişkilerin incelenmesi [Unpublished master's thesis]. Kastamonu University.

Kasalak, G. (2020). Öğretmenlerin algıladıkları örgütsel desteğin örgütsel sonuçları üzerindeki etkisi: Bir meta-analiz çalışması. Journal of Business and Human, 7(1), 119-135. doi: 10.18394/iid.572572

Kılıç, E. (2019). Okul yöneticilerinin paternalist liderlik düzeyleri ile öğretmenlerin örgütsel destek algıları arasındaki ilişki [Unpublished master's thesis]. Uşak University.

Kılınç, A. Ç., Cemaloğlu, N., \& Savaş, G. (2015). The relationship between teacher leadership, teacher professionalism, and perceived stress. Eurasian Journal of Educational Research, 58, 1-26. doi: 10.14689/ejer.2015.58.5

Kılınç, A. Ç., \& Recepoğlu, E. (2013). Ortaöğretim okulu öğretmenlerinin öğretmen liderliğine ilişkin algı ve beklentileri. Kalem Uluslararası Eğitim ve Insan Bilimleri Dergisi, 3(2), 175-215.

Koşar, D., Er, E., Kılınç, A. Ç., \& Koşar, S. (2017). Öğretmen liderliğine ilişkin yapılan çalışmaların incelenmesi: Bir içerik analizi çalışması. Inönü Üniversitesi Ĕgitim Bilimleri Enstitüsü Dergisi, 4(7), 29-46. doi: 10.29129/inujgse.317712

Kurt, T. (2016). Öğretmen liderliğini açıklamaya yönelik bir model: dağıtımcı liderlik, örgütsel öğrenme ve öğretmenlerin öz yeterlik algısının öğretmen liderliğine etkisi. Eğitim ve Bilim, 41(183), 1-28. doi: 10.15390/EB.2016.5081

Meriç, E., Öztürk Çiftci, D., \& Yurtal, F. (2019). Algılanan örgütsel destek ve işe adanmışlık arasındaki ilişkinin incelenmesi. Kastamonu Education Journal, 27(1), 65-74. doi: 10.24106/kefdergi.2296

Meydan, C. H. \& Şeşen, H. (2011). Yapısal eşitlik modellemesi amos uygulamaları. Ankara: Detay Yayıncılık.

Meyer, J. P., Stanley, D. J., Herscovitch, L., \& Topolnytsky, L. (2002). Affective, continuance, and normative commitment to the organization: A meta-analysis of antecedents, correlates, and consequences. Journal of Vocational Behavior, 61(1), $20-52$. https://doi.org/10.1006/jvbe.2001.1842

Miao, R. T. (2011). Perceived organizational support, job satisfaction, task performance and organizational citizenship behavior in China. Journal of Behavioral and Applied Management, 12(2), 105-127. doi: 10.21818/001c.17632

Muijs, D., \& Harris, A. (2006). Teacher led school improvement: Teacher leadership in UK. Teaching and Teacher Education, $22(8), 961$ - 972. doi: 10.1016/j.tate.2006.04.010

Nartgün, Ş. S., \& Kalay, M. (2014). Öğretmenlerin örgütsel destek, örgütsel özdeşleşme ile örgütsel sinizm düzeylerine ilişkin görüşleri. Turkish Studies, 9(2), 1361-1376. doi: 10.7827/TurkishStudies.6414

Nayır, F. (2011). Ilköğretim okulu yöneticilerinin öğretmenlere sağlanan örgütsel desteğe ilişkin görüşleri, öğretmenlerin örgütsel destek algısı ve örgütsel bağıııkla ilişkisi [Unpublished doctoral dissertation]. Ankara University.

Nayır, F. (2012). The relationship between perceived organizational support and teachers' organizational commitment. Eurasian Journal of Educational Research, 12(48), 97-116.

Ovacıklı, S. (2018). Illkokul müdürlerinin öğretmen liderliğini destekleyici davranışları ile öğretmen liderliği arasındaki ilişkinin incelenmesi [Unpublished master's thesis]. Dokuz Eylül University.

Önder, E., \& Küpeli, B. (2018). Öğretmen liderliğine ilişkin ortaöğretim öğretmenlerinin görüşleri. International Congress of Eurasian Social Sciences (ICOESS), Antalya, 6-7 Nisan 2018. http://semp.ijoess.com/upload/213dacf6-f788-4602-bde6-82b1396799ef.pdf

Özdevecioğlu, M. (2003). Algılanan örgütsel destek ile örgütsel bağlılık arasındaki ilişkilerin belirlenmesine yönelik bir araştırma. Dokuz Eylül Üniversitesi Iktisadi İari Bilimler Fakültesi Dergisi, 18(2), 113 -130.

Öztürk, N., \& Şahin, S. (2017). Eğitim örgütlerinde örgüt kültürü ve öğretmen liderliği: Lider-üye etkileşiminin aracılık rolü. Elementary Education Online, 16(4), 1451-1468. doi: 10.17051/ilkonline.2017.342967

Tanrıverdi, H., \& Kılıç, N. (2016). Algılanan örgütsel destek ve örgütsel yabancılaşma arasındaki ilişkinin incelenmesi. Hacettepe Üniversitesi, Sosyolojik Araştırmalar E-Dergisi, 1(1), 1-18.

Turan Dallı, H. (2018). Anadolu Lisesi öğretmenlerinin denetim odağı, özgüven ve algılanan örgütsel destek ile örgütsel sessizlik algıları arasındaki ilişki [Unpublished master's thesis]. Gazi University.

Riggle, R. J., Edmondson, D. R., \& Hansen, J. D. (2009). A meta-analysis of the relationship between perceived organizational support and job outcomes: 20 years of research. Journal of Business Research, 62(10), 1027-1030. doi: 10.1016/j.jbusres.2008.05.003

Rhoades, L., \& Eisenberger, R. (2002). Perceived organizational support: A review of the literature. Journal of Applied Psychology, 87(4), 698714. https://doi.org/10.1037/0021-9010.87.4.698

Rutherford, C. (2006). Teacher leadership and organizational structure the implications of restructured leadership in an Edison school. Journal of Educational Change, 7(1), 59-76. doi: 10.1007/s10833-006-0013-4

Savaş, G. (2016). Okul müdürlerinin destekleyici davranışları ile öğretmen liderliği arasındaki ilişki ve bazı değişkenlere göre incelenmesi [Unpublished master's thesis]. Gazi University.

| Kastamonu Education Journal, 2021, Vol. 29, No. 5 | 
Schermelleh-Engel, K., Moosbrugger, H., \& Muller, H. (2003). Evaluating the fit of structural equation models: Tests of significance and descriptive goodness-of-fit measures. Methods of Psychological Research-Online, 8(8), 23-74.

Sugg, S. A. (2013). The relationship between teacher leadership and student achievement Unpublished doctoral dissertation]. Eastern Kentucky University.

Terzi, A. R., \& Çelik, H. (2016). Okul yöneticilerinin liderlik stilleri ve algılanan örgütsel destek ilişkisi. Eğitim ve Öğretim Araştırmaları Dergisi, 5(2), 2146-9199.

Tsui, A. S., Pearce, J. L., Porter, L. W., \& Tripoli, A. M. (1997). Alternative approaches to the employee-organization relationship: Does investment in employees pay off? Academy of Management Journal, 4O(5), 1089-1121. https://doi.org/10.2307/256928

Uğur, F. (2017). Ortaokul öğretmenlerinin algılanan örgütsel destek düzeyi ile örgüt sağlığı arasındaki ilişki [Unpublished master's thesis]. Yeditepe University.

Uğurlu, C. T., \& Yiğit, Y. (2014). Öğretmenlerin öğretmen liderliği algılarının örgütsel vatandaşlık davranışlarına etkisi. Buca Eğitim Fakültesi Dergisi, 38, 36-56.

Uzun, T. (2018). Öğretmenlerin algıladığı örgütsel destek ile örgütsel özdeşleşme ve işten ayrılma niyeti arasındaki ilişki: Örgütsel güvenin aracı rolü. Karadeniz Sosyal Bilimler Dergisi, 10(18), 133-155.

Way, S. A., Sturman, M. C., \& Raab, C. (2010). What matters more: Contrasting the effects of job satisfaction and services climate on hotel food and beverage managers' job performance. Cornell Hospitality Quarterly, 51(3), 379-397. doi: 10.1177/1938965510363783

Wayne, S. J., Shore, L. M., \& Liden, R. C. (1997). Perceived organizational support and leader-member exchange: A social exchange perspective. Academy of Management Journal, 40(1), 82-111. doi: 10.2307/257021

Wenner, J. A., \& Campbell, T. (2017). The theoretical and empirical basis of teacher leadership: A review of the literature. Review of Educational Research, 87(1), 134-171. https://doi.org/10.3102/0034654316653478

Yılmaz, A. I. (2018). Okullardaki bürokratik yapı ve öğretmen liderliği arasındaki ilişki [Unpublished doctoral dissertation]. Dokuz Eylül University.

Yılmaz, K., Oğuz, A., \& Altınkurt, Y. (2017). Öğretmenlerin liderlik davranışları ile öğrenen özerkliğini destekleme davranışları arasındaki ilişki. Hacettepe Üniversitesi Eğitim Fakültesi Dergisi, 32(3),659-675. https://doi.org/10.16986/HUJE.2016016394

York-Barr, J., \& Duke, K. (2004). What do we know about teacher leadership? Findings from two decades of scholarship. Review of Educational Research, 74(3), 255-316. https://doi.org/10.3102/00346543074003255

Yoshimura, K.E. (2003). Employee traits perceived organizational support supervisory communication affective commitment and intent to leave: Group differences (Master's thesis). North Carolina State University. 